\title{
EDITORIAL
}

\section{Literatura, cinema e gastronomia}

Há muito tem se discutido o diálogo entre literatura e cinema. É provável que a obra $L$ 'Age $d u$ roman américain (1948), do francês Claude Edmonde-Magny, tenha sido a primeira a tratar dessa fraterna camaradagem. Na trilha de John dos Passos, que, em 1938, ao publicar sua trilogia USA, deu o nome de camera eyes a alguns de seus capítulos, Magny, incluindo autores como Hemingway, Steinbeck e Faulkner, tentou traçar um paralelismo entre a escritura literária e a cinematográfica. A partir disso, proliferaram-se algumas imprecisões e muita polêmica, sobretudo porque, à época, a crítica cinematográfica trilhava caminho inverso à literária. A ideia de que uma câmera era uma caneta, e podia exprimir algo tão abstrato e profundo quanto a escrita se espalhou e se tornou um clichê.

Hiroshima mon amour, de Resnais e Duras, lançado em 1958, consagra essa colaboração inteiramente nova entre a literatura e o cinema. De lá para cá, a camaradagem só se acentuou. Contudo, o cinema tem braços largos e fez da arte da gastronomia o mote de muitas de suas obras, traçando um imbróglio entre os dois e a literatura.

Não sem tempo, vale a pena relembrar Como água para chocolate, cujo roteiro, de Laura Esquivel (também baseado em seu romance homônimo), conta a história de Tita, que nasce na cozinha da família, quando a mãe descascava cebolas. Não menos célebres são $A$ Festa de Babette, de Gabriel Axel, baseado no conto de Karen Blixen, e Os Sabores do Palácio, de Christien Vicent, livremente inspirado na vida da cozinheira de François Mitterand, presidente francês.

Ao idearmos o dossiê "Literatura, cinema e gastronomia", pensamos em diferentes obras ficcionais que adentraram as telas de cinema e provocaram esta intermidialidade já tão cediça nesses dias em que o olhar se desloca do texto à tela sem qualquer timidez, razão, afirmam alguns, de havermos nos tornado 'visuais' em demasia. O paladar, pensamos, só faria aguçar os sentidos e fazer do leitor/espectador gourmet de um pantagruélico banquete. Em fase de publicação, notamos que nossos autores cruzaram sensações, associaram palavras, expressões, 


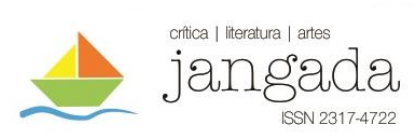

gêneros e memórias, enfim, tornaram-se de fato sinestésicos e tomaram a literatura em seu sentido figurado e abrangente, partiram para a biografia (que ganhou as telas) e revisitaram os livros de receitas da vovó, que viraram volume, e permitiram que pesquisadores recuperassem um pouco de nossa brasilidade.

Nosso número, abre-se com a contribuição de Cristine Maccarone e Luiz Antonio Vadico, cujo texto "Da ceia à cena: os alimentos na vida e na obra de Alfred Hithcock" perpassa nada menos que 52 das 53 produções do icônico diretor britânico, em busca das diferentes características e utilizações que os alimentos imprimiram às suas obras. De quebra, os autores lançaram um olhar de míope sobre os gostos pessoais de Hithcock. E uma vez que referências biográficas vieram à tona, em “Toast” Isis Fonseca Sá se debruça sobre as relações entre literatura e cinema a partir da biografia de Nigel Slater, obra recheada de memórias culinárias e afetivas que, levada às telas, conferiu às torradas status de memória involuntária.

“Rua, casa, comida: 'Os Primos Basílios' e suas mulheres, na literatura, no cinema e na TV”, de José Roberto de Andrade e Verônica Almeida Santos, leva o leitor ao universo eciano ao compor dois eixos: o das mulheres, Luísa, Leopoldina, Juliana e Joana, e o intermidial, jogo em que a obra literária e sua representação na TV e no cinema, abrem fissuras para a discussão do feminino em seus espaços de circulação. "O Ensaio sobre a cegueira e a interdição ao sabor: literatura, cinema e práticas discursivas de sujeição", de Éderson Luís da Silveira e Rodrigo de Freitas Faqueri, traça um panorama entre a obra de Saramago e a do diretor Fernando Meirelles. No artigo, os autores, sustentam que "nas obras ficcionais, a interdição dos alimentos é discursiva e remete ao terreno das práticas em que alguns são proibidos e outros são os que decidem, negligenciando-se princípios éticos para coisificar mulheres como moeda de troca aproximando as relações humanas de um viés utilitarista".

Em “ $L$ 'Amant de la Chine du Nord: roteiro romanesco entre cinema e literatura”, Maria do Socorro Aguiar Pontes Giove discorre sobre o efeito bumerangue produzido pela adaptação de L'Amant, obra de Maguerite Duras, levada às telas pelo francês Jean-Jacques Annaud, cujo resultado não a agradou. Desta feita, Duras, insatisfeita, produz L'Amant de la Chine $d u$ Nord, misto de romance e roteiro cinematográfico.

“Aproximações entre literatura e cinema: narradores não confiáveis de Dom Casmurro e Anticristo", de Renata Del Moro, analisa a obscuridade dessa figura de matiz machadiano, o narrador não confiável, em contraponto com o narrador de similar progênie de Anticristo, filme do cineasta Lars Von Trier. Del Moro investiga como temas de grande interesse ao texto literário e à técnica cinematográfica são trazidos à luz por meio aproximação. 


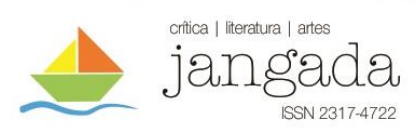

Joseana Stringini da Rosa, em "Transposição intermidiática: diálogo entre literatura e cinema", analisa a intermidialidade, qual seja, a transposição de uma mídia para outra, do livro para a tela, a partir da graphic novel Le bleu est une couleur chaude, fonte do diretor Abdellatif Kechiche para a realização do filme La Vie d'Adèle.

Em “A construção do personagem Arthur por meio de sua conexão com a cozinha no romance de The Solid Mandala, de Patrick White", Monica Stefani elenca como a fabricação do pão e da manteiga, fazeres prediletos de Arthur, favorece a construção narrativa, a elaboração de tramas, suas repercussões e a construção identitária da personagem no romance do australiano Patrick White, Nobel de Literatura.

Paula de Oliveira Feliciano, em "Literatura e construção de uma brasilidade pela literatura" (1840-1960), traça um panorama da produção de livros de receitas, sobretudo no que tange à materialização e cristalização de símbolos e expressões que compõem a cultura material e imaterial, consubstanciando, dessa forma, para a criação de certa brasilidade. Para tanto, Feliciano lança mão das reflexões de Mário de Andrade sobre o assunto.

Encerrado nosso dossiê, iniciamos a seção de artigos com “Lágrimas fracas, dores mínimas, chuvas outonais': a poética da melancolia em três escritoras lusófonas”, em que Juan Filipe Stacul investiga as relações de enunciação e literatura em três nomes da poesia contemporânea em língua portuguesa (Noémia de Sousa, Florbela Espanca e Ana Cristina Cesar) de modo perscrutar a constituição de uma poética da melancolia nas autoras. $\mathrm{Na}$ sequência, temos "Considerações sobre a morte e suas diversas facetas em $O$ Estrangeiro, de Albert Camus", em que Mariana Almeida Varela discorre sobre aspectos da "recepção" da indesejada das gentes e suas implicações na obra-prima de Albert Camus, traçando um panorama em que a morte sedimenta uma das filosofias caras a Camus, o "absurdo".

Em “Traços de um rascunho pós-dramático: “... é o que fica.”, Paulo Henrique de Oliveira e Juan Filipe Stacul, investigam a presença dos modos de criação cênica a partir de alguns elementos da Dança-teatro e do Teatro-físico no Teatro Pós-dramático, constituindo-se em um relato de experiência cuja origem foi o conto "A caixinha de música", de Caio Fernando de Abreu como mola propulsora.

E, para finalizar, apresentamos o conto "O Ladrão", de Junichiro Tanizake, renomado escritor japonês, traduzido por Renan Kenji Sales Hayashi, instigante oportunidade ao leitor brasileiro de mergulhar na ficção de Tanizake, ao acompanhar o périplo de um ladrão pela Tóquio de meados do século XX. 
O conjunto de trabalhos que perfaz este dossiê, somado aos demais artigos e à tradução, não só revela uma multiplicidade de temas de pesquisas, como também contribui para o nosso intuito de solidificar a Revista Jangada como veículo de expressão de conhecimento produzido no universo das Humanidades.

A todos, desejamos uma ótima leitura, um bom filme e um bon appétit!

Dirceu Magri Elaine Cristina Cintra Editores deste número 